\title{
Calamagrostis epigeios (L.) Rotch на разновозрастных золоотвалах Нижнетуринской ГРЭС
}

\section{Calamagrostis epigeios (L.) Rotch on uneven-age ash dumps of the Nizhneturinskaya GRES}

\author{
Глазырина М. А., Лукина Н. В., Филимонова Е. И., Чибрик Т. С., Раков Е. А. \\ Glazyrina M. A., Lukina N. V., Filimonova E. I., Chibrik T. S., Rakov E. A. \\ ${ }^{l}$ Уральский федеральный университет имени первого Президента России Б. Н. Ельиина, г. Екатеринбург, Россия. \\ E-mail:puma2531@mail.ru; natalia.lukina@urfu.ru; Elena.Filimonova@urfu.ru; Tamara.Chibrik@urfu.ru; E.A.Rakov@urfu.ru
}

${ }^{1}$ Ural Federal University named after the first President of Russia B. N. Yeltsin, Ekaterinburg, Russia

Peфераm. В статье представлены результаты изучения ценопопуляций Calamagrostis epigeios (L.) Rotch, произрастающих на разновозрастных золоотвалах Нижнетуринской государственной районной электростанции (НТГРЭС), расположенных в таежной зоне. Изучение пространственной структуры ценопопуляций $C$. epigeios показало, что на золоотвалах НТГРЭС для данного вида характерен групповой тип распределения побегов. Установлено, что с увеличением возраста ценопопуляций происходит увеличение общей биомассы вида на единицу площади за счет роста плотности ценобионтов и развития более крупных генеративных побегов. Рост плотности ценобионтов приводит к уменьшению размеров вегетативных побегов. C. epigeios является главным компонентом растительных сообществ при самозарастании золоотвалов. В экстремальных эдафических условиях данный вид формирует устойчивые продуктивные сообщества.

Ключевые слова. Золоотвал, вегетативно подвижные растения, растительные сообщества, ценопопуляция, фитоценоз, Calamagrostis epigeios (L.) Rotch.

Summary. The article presents the results of the study of Calamagrostis epigeios (L.) Rotch cenopopulations, growing on uneven-age ash dumps of Nizhneturinskaya state district power plant (NTGRES), located in the taiga zone. The study of the spatial structure of $C$. epigeios coenopopulations showed that the group type of shoots distribution is typical for this kind of NTGRES ash dumps. It has been established that with an increase in the age of cenopopulations, the total biomass of the species per unit area increases due to an increase in the density of cenobionts and the development of larger generative shoots. An increase in the density of cenobionts leads to a decrease in the size of vegetative shoots. C. epigeios is the main component of plant communities during self-overgrowing of ash dumps. Under extreme edaphic conditions, this species forms stable productive communities.

Key words. Ash dump, Calamagrostis epigeios (L.) Rotch, coenopopulation, plant communities, phytocenosis, vegetative mobile plants.

\section{Введение}

Современные темпы разработки полезных ископаемых, деятельность перерабатывающих комбинатов и т. п., нередко приходят в противоречие с проблемой сохранения природы. Вокруг городов с развитой промышленностью образуются так называемые индустриальные пустыни, горы отвалов пустой природы, которые занимают огромные площади и негативно влияют на природно-территориальные комплексы и жизненную среду человека. К таким глобальным антропогенным нарушениям относятся золоотвалы тепловых электростанций, площади которых достигают десятков и сотен гектаров. Сразу после окончания эксплуатации они становятся опасными очагами загрязнения окружающей среды, оказывающими негативное влияние на почвенный и растительный покровы, тем самым отрицательно воздействуя на естественные природные комплексы. Зарастание подобных территорий происходит крайне медленно. 
Важную роль в процессе самозарастания золоотвалов играют вегетативно подвижные растения. Одним из таких видов растений является Calamagrostis epigeios (L.) Rotch, который поселяется на золоотвалах и других типах нарушенных земель, и, зачастую, становится доминантом и эдификатором растительных сообществ на ранних стадиях сукцессий.

C. epigeios (сем. Poaceae Barnhart) - многолетнее травянистое поликарпичекое длиннокорневищное растение с вневлагалищным типом возобновления побегов. Имеет два типа побегов: укороченные вегетативные и генеративные (Уланова, 1995). Нетребователен к почвам, хоть и предпочитает сухие песчаные и супесчаные почвы, но может произрастать и на суглинистых, известняковых, черноземных, солонцеватых, аллювиальных. Выносит значительное засоление. Из-за своей высокой пластичности Calamagrostis epigeios поселяется на нарушенных землях, в том числе и на золоотвалах. Его корневища, образующие дернину, закрепляют зольный субстрат, в результате чего уменьшается ветровая и водная эрозия. Также он обогащает зольный субстрат органическими и минеральными веществами, активизируя деятельность почвенной микрофлоры. Вследствие этого создаются условия для прохождения последующих стадий сингенеза формирующимися растительными сообществами.

Целью данной работы является изучение структуры ценопопуляций (ЦП), а также морфологических параметров особей $C$. epigeios на золоотвалах Нижнетуринской государственной районной электростанции (НТГРЭС).

\section{Материалы и методы}

Исследования проводились на двух золоотвалах НТГРЭС, расположенных рядом с г. Нижняя Тура (Средний Урал, Свердловская область, таежная зона, граница подзон южной и средней тайги). Район исследований находится в умеренно-континентальной бореальной климатической зоне. Коренная растительность района исследований представлена сосновыми, реже сосново-еловыми лесами. Широко распространены производные березовые леса. Среднегодовая температура в районе составляет $0,7^{\circ} \mathrm{C}$. В год выпадает около 673 мм осадков. Наибольшее количество осадков выпадает в летний период (Шакиров, 2011).

Золоотвал № 1 находится в 2 км на северо-восток от НТГРЭС в естественном котловане с глубиной залегания пласта золы 12-15 м и площадью 60 га. Ландшафтное окружение - застроенные земли и сельскохозяйственные угодья. Эксплуатация золоотвала была закончена в 1957 г. Часть территории была рекультивирована (перекрыта 2 см слоем грунта), часть оставлена для самозарастания.

Золоотвал № 2 расположен в 19 км от г. Нижняя Тура на месте бывшего Вогульского болота и занимает около 440 га. Золоотвал заливался пульпой с 1992 г. посекционно, работы на последнем участке завершены в 2015 г, каких-либо рекультивационных мероприятий на нем не проводилось. Антропогенное влияние на процесс самозарастания минимально. Зарастание золоотвала осуществляется за счет заноса семян из окружающих его со всех сторон сосновых лесов и заболоченных территорий (Чибрик и др., 2016).

Геоботаническое обследование золоотвалов проводилось детально-маршрутным методом с описанием растительности по общепринятым методикам (Полевая геоботаника, 1964).

ЦП C. epigeios были изучены на рекультивированном (золоотвал № 1, ЦП1) и нерекультивированном (золоотвал № 2 ЦП2) золоотвалах НТГРЭС. Для сравнительной характеристики плотности, возрастной и морфологической структуры ЦП в качестве «фитоценотической счетной единицы» (ценобионта) рассматривались парциальные побеги (Ценопопуляция растений..., 1976). Для морфологического анализа C. epigeios на золоотвалах было взято по 100 вегетативных и по 40 генеративных побегов. Анализ генеративных ценобионтов данного вида проводился по 11 параметрам: высота побега (см), число узлов на удлиненной части побегов, шт.; число живых листьев (шт.); параметры срединного листа -длина (см), ширина (см), длина соцветий (см), число мутовок в соцветии (шт.), число веточек в мутовках (шт.), число колосков во 2-й мутовке (шт.), масса соцветия (г) и побега (г). Морфологический анализ вегетативных побегов был проведен по 3 параметрам: высота побега (см), число живых листьев (шт.), масса побега (г). Экспериментальный материал был обработан на персональном компьютере с помощью пакета прикладных программ «Microsoft Excel 2010» и стандартными методами математической статистики, с помощью программы «Statistika 10». 


\section{Результаты и их обсуждение}

К 2016 г., через 55 лет после проведения биологической рекультивации, на золоотвале № 1 (на «чистой» золе) сформировался вейниковый фитоценоз с доминированием C. epigeios (soc), единично встречаются Achillea millefolium L., Bromopsis inermis (Leyss.) Holub, Pimpinella saxifraga L. Общее проективное покрытие растительности (ОПП) составляло 80-100\%. Изучение веса надземной и подземной фитомассы показало, что фитомасса подземных органов $(626,81$ г/м²) в 4,1 превышает фитомассу

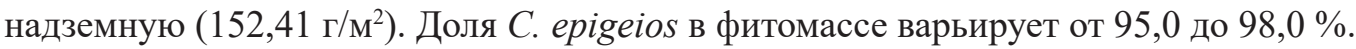

На высыхающих участках золоотвала № 2 к 20-25-летнему возрасту зафиксированы начальные этапы формирования смешанных лесных фитоценозов с преобладанием Betula pendula Roth и Pinus sylvestris L., с подростом лиственных (Populus tremula L. и Betula pubescens Ehrh.) и хвойных (Picea obovata Ledeb., Pinus sibirica Du Tour, Larix sibirica Ledeb.) пород деревьев. В травянистом ярусе доминирует C. epigeios, группами встречаются Chamaenerion angustifolium (L.) Scop., Deschampsia cespitosa (L.) Beauv., Equisetum arvense L. и (sp gr) др. ОПП травянистого яруса в среднем составляет 30-40 \%, варьируя от 10 до $70 \%$. Вес подземной фитомассы травянистых видов $(356,60$ г/м²) в 2,5 раза больше, чем вес надземной фитомассы $\left(145,69 \Gamma / \mathrm{M}^{2}\right)$.

Изучение пространственной структуры ЦП C. epigeios по результатам анализа площадок, заложенных в виде трансект показало, что на золоотвалах НТГРЭС для данного вида характерен групповой тип распределения побегов (ЦП $-\mathrm{S}^{2} / \mathrm{m}=3,4$; коэффициент встречаемости $(К \mathrm{~B})=80 \%$; ЦП2 $\left.\mathrm{S}^{2} / \mathrm{m}=5,4 ; \mathrm{KB}-71 \%\right)$. Среднее количество побегов C. epigeios в ЦП1 составляет 198,6 шт. на 1 м $^{2}$, ЦП2 - 49,7 шт. на 1 м². Для ЦП характерно преобладание генеративных побегов (97 и 93 \% соответственно) (табл. 1).

Таблица 1

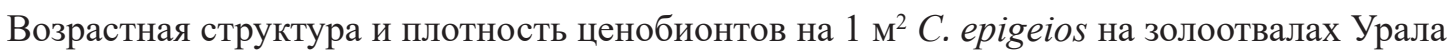

\begin{tabular}{|c|c|c|c|c|c|c|}
\hline \multirow{2}{*}{ Местообитание } & \multirow{2}{*}{$\begin{array}{c}\text { ОПП } \\
\text { травя-нистых, } \\
\%\end{array}$} & \multicolumn{2}{|c|}{$\begin{array}{c}\text { Число ценобионтов, } \\
\text { шт./M }{ }^{2} \\
\end{array}$} & \multicolumn{2}{|c|}{ Возрастная структура } & \multirow{2}{*}{$\begin{array}{c}\mathrm{KB}, \\
\%\end{array}$} \\
\hline & & Xcp. & $\lim$ & $\begin{array}{c}\text { Доля g } \\
\text { побегов, \% }\end{array}$ & $\begin{array}{c}\text { Доля v } \\
\text { побегов, \% }\end{array}$ & \\
\hline $\begin{array}{c}\text { Золоотвал № } 1 \\
\text { (рекультивированный) }\end{array}$ & $25-90$ & 198,6 & $0-592$ & 3 & 97 & 80 \\
\hline $\begin{array}{c}\text { Золоотвал № } 3 \\
\text { (нерекультивированный) }\end{array}$ & $10-50$ & 49,7 & $0-104$ & 7 & 93 & 71 \\
\hline
\end{tabular}

Примечание: ООП - общее проективное покрытие растительности; КВ - коэффициент встречаемости.

В вертикальной структуре травостоя C. epigeios было выявлено два основных яруса. I ярус образуют генеративные побеги с высотой от 39,5 до 116,0 см (в среднем 83,21 см) - ЦП1, и 46,3-102,8 см (в среднем 77,9 см) - ЦП2 (табл. 2). Генеративные побеги выше на золоотвале № 1. Высота генеративных побегов ЦП1 изменяется в пределах от 39,5 до 116,0 см, ЦП2 - от 46,3 до 102,8 см. Среднее значение высоты побега составляет 83,2 см и 77,9 см соответственно.

Основная масса вегетативных побегов находится во II ярусе. Высота вегетативных побегов колеблется от 15 до 49 см (в среднем 33,7 см) - ЦП1, и 15,1-91,5 см (в среднем 44,4 см) - ЦП 2.

Морфологический анализ срединного листа генеративных ценобионтов показал, что длина больше на золоотвале № 2, а ширина - на золоотвале № 1 (табл. 2). Среднее значение длины соцветий, число веточек в мутовках, число колосков во второй мутовке генеративных ценобионтов больше на золоотвале № 2, чем на золоотвале № 1 (табл. 2).

Масса генеративных побегов C. epigeios на золоотвале № 1 в 1,8 раз больше, чем на золоотвале № 2, а масса вегетативных побегов 1,3 раза меньше.

По результатам t-test статистического анализа морфологических показателей генеративных ценобионтов $C$. epigeios на золоотвалах НТГРЭС было установлено, что различия между вариантами по таким параметрам как: число живых листьев, длина соцветий, число колосков во второй мутовке, мас- 
са побега - являются достоверными. По остальным показателям отличия являются недостоверными. А у вегетативных ценобионтов C. epigeios выявлены достоверные различия между вариантами по таким параметрам как: высота побега, число живых листьев и масса побега (табл. 2).

Таблица 2

Некоторые биометрические параметры ценобионтов C. epigeios

\begin{tabular}{|c|c|c|c|c|c|c|}
\hline \multirow[b]{2}{*}{ Показатель } & \multicolumn{3}{|c|}{ Золоотвал № 1} & \multicolumn{3}{|c|}{ Золоотвал № 2} \\
\hline & $\mathrm{Xcp} . \pm \mathrm{m}$ & $\lim$ & $\begin{array}{l}\mathrm{Cv}, \\
\%\end{array}$ & $\mathrm{Xcp} . \pm \mathrm{m}$ & $\lim$ & $\mathrm{Cv}, \%$ \\
\hline \multicolumn{7}{|c|}{ Генеративные } \\
\hline Высота побега, см & $83,2 \pm 2,39$ & $39,5-116$ & 18 & $77,9 \pm 5,91$ & $46,3-102,8$ & 30 \\
\hline Число живых листьев, шт.* & $1,7 \pm 0,12$ & $1-4$ & 41 & $2,4 \pm 0,24$ & $2-4$ & 30 \\
\hline $\begin{array}{l}\text { Параметры срединного листа: } \\
\text { длина, см }\end{array}$ & $23,4 \pm 0,93$ & $12,5-34,5$ & 25 & $25,8 \pm 1,60$ & $20-37$ & 19 \\
\hline ширина, см & $0,5 \pm 0,02$ & $0,4-0,8$ & 21 & $0,5 \pm 0,05$ & $0,35-0,8$ & 29 \\
\hline Длина соцветий, см* & $12,7 \pm 0,41$ & $8-17,5$ & 20 & $14,8 \pm 0,83$ & $9,6-17,3$ & 18 \\
\hline Число мутовок в соцветии, шт. & $13,8 \pm 0,21$ & $11-15$ & 10 & $13,2 \pm 0,57$ & $11-15$ & 14 \\
\hline Число веточек в мутовках, шт. & $48,6 \pm 1,13$ & $37-62$ & 14 & $53,3 \pm 2,41$ & $41-65$ & 14 \\
\hline Число колосков во 2-й мутовке, шт.* & $124,3 \pm 7,14$ & $51-223$ & 35 & $188,2 \pm 26,87$ & $41-314$ & 45 \\
\hline Масса соцветия, г & $0,2 \pm 0,02$ & $0,09-0,45$ & 44 & $0,2 \pm 0,03$ & $0,05-0,36$ & 45 \\
\hline Масса побега, г* & $1,5 \pm 0,08$ & $0,43-2,97$ & 34 & $0,83 \pm 0,11$ & $0,4-1,65$ & 45 \\
\hline \multicolumn{7}{|c|}{ Вегетативные } \\
\hline Высота побега, см* & $33,73 \pm 0,67$ & $15-49$ & 20 & $44,39 \pm 1,14$ & $15,1-91,5$ & 30 \\
\hline Число живых листьев, шт.* & $2,08 \pm 0,46$ & $1-3$ & 22 & $2,37 \pm 0,07$ & $1-4$ & 32 \\
\hline Масса побега, г* & $0,18 \pm 0,01$ & $0,02-0,49$ & 6 & $0,24 \pm 0,01$ & $0,01-0,88$ & 67 \\
\hline
\end{tabular}

Примечание: * По результатам t-test различия между вариантами являются достоверными.

Таким образом, исследования показали, что с увеличением возраста ценопопуляций C. epigeios происходит увеличение общей биомассы вида на единицу площади за счет роста плотности ценобионтов и развития более крупных генеративных побегов. Рост плотности ценобионтов приводит к уменьшению размеров вегетативных побегов.

C. epigeios является главным компонентом растительных сообществ при самозарастании золоотвалов. В экстремальных эдафических условиях данный вид формирует устойчивые продуктивные сообщества.

Благодарности. Работа выполнена при финансовой поддержке со стороны Министерства науки и высшего образования Российской Федерации в рамках выполнения государственного задания УрФУ № 6.7696.2017/БЧ.

\section{ЛИТЕРАТУРА}

Полевая геоботаника. В 5 т. - Л.: Наука, 1964. - Т. 3. - 530 с.

Уланова Н. Г. Вейник наземный // Биологическая флора Московской области. - М.: Изд-во Московского ун-та и «Аргус», 1995. - Вып. 10. - С. 4-19.

Ценопоуляции растений (основные понятия и структура) / О. В. Смирнова, Л. Б. Заугольнова, И. М. Ермакова [и др.]. - М.: Наука, 1976. - 217 с.

Чибрик Т. С., Раков Е. А., Филимонова Е. И., Глазырина М. А., Лукина Н. В. Биологический мониторинг восстановления растительности на Нижнетуринском золоотвале / Биодиагностика состояния природных и природно-техногенных систем: Материалы Всерос. науч.-практ. конф. с межнар. участием. Книга 2. (г. Киров, 5-8 декабря 2016 г.). - Киров: ООО «Издательство «Радуга-ПРЕСС», 2016. - С. 155-159.

Шакиров А. В. Физико-географическое районирование Урала. - Екатеринбург: УрО РАН, 2011. - С. 618 с. 